Agro-Science Journal of Tropical Agriculture, Food, Environment and Extension Volume 8 Number 2 May 2009 pp 104-109

ISSN1119-7455

\title{
EVALUATION OF NEW GENERATIONS OF MAIZE STREAK VIRUS (MSV) RESISTANT VARIETIES FOR GRAIN YIELD, AGRONOMIC POTENTIAL AND ADAPTATION TO A SOUTHERN GUINEA SAVANNA ECOLOGY OF NIGERIA
}

\author{
Olaoye G. \\ Department of Agronomy University of Ilorin \\ P.M.B. 1515, Ilorin, Nigeria.
}

\begin{abstract}
Five new generations of maize streak virus (MSV) resistant varieties were evaluated along with two checks in replicated trials and for two years in a southern guinea savanna ecology of Nigeria, which is an endemic zone for the disease. Difference in grain yield between favourable growing season in 2002 and unfavourable season in 2001 was $1.68 \mathrm{t}^{-\mathrm{ha}^{-1}}$, representing $30.2 \%$ yield increase of 2001 performance. Results further showed that while both rust and streak diseases appeared to have been put in check, the genotypes showed slight susceptibility to leaf blight and curvularia leaf spot, ranging from 5-7 and 4-8 percent (\%) respectively. Genotypic differences were significant for grain yield, agronomic traits as well as incidences of leaf blight and curvularia leaf spot. Acr 91 Suwan-1$S R C_{1}$ was the most productive of new generations of MSV resistant varieties, having yielded significantly higher than OPV check by 32 percent (\%) and comparable with the hybrid check for grain yield. The variety could therefore serve as replacement to existing cultivar and also as source of genes for future maize breeding activities in the development of superior maize varieties for the southern guinea savanna ecology.
\end{abstract}

Key words: Genotypes, grain yield, leaf diseases, adaptation. e-mail: debolaoye @ yahoo.com

\section{INTRODUCTION}

Maize (Zea mays L.) production in tropical Africa is constrained by a number of stress factors including a complex of insect and disease organisms that significantly reduce the quantity and quality of production (Fajemisin et al., 1984; Fajemisin, 1985, Fajemisin et al., 1985; Mihm, 1994). In Nigeria, maize streak virus (MSV) disease which is transmitted by the aphids (Cicadulina species), reduces maize grain yield particularly during the late cropping season once there is a prolong drought spell. The disease reached epiphytotic level in Nigeria in the 1970's, causing significant yield loss in endemic zones (Fajemisin, 1984). Although collaborative research efforts by maize scientists at both international centres and national agricultural research systems has succeeded in converting established varieties and breeding populations from different sources to streak resistant (Fakorede et al., 2001), newly developed varieties meant for cultivation in endemic zones, normally have genes for streak resistance incorporated into them at one stage of development or the other. One of the major constraints in varietal development is the evolution of a virulent strain to which previously resistant varieties may be susceptible (Fakorede et al., 2001). For example, survey of leaf diseases in the south western Nigeria showed that occurrence of other maize leaf diseases such as maize leaf rust (Pucinia polysora); maize leaf spots (Curvularia lunata) and maize ear rot (Fusarium moniliforme) are on the increase (Olakojo and Iken, 1999).Therefore, newly developed maize varieties are routinely evaluated in various agro-ecological zones for adaptation, yield potential and disease reactions, to identify genotypes that can replace existing cultivars and as part of the requirements for releasing suitable varieties for cultivation in farmers' fields (Olakojo and Iken, 2001). Furthermore, since every agroecology has unique growing conditions, it is important to assess newly developed varieties for yield potentials as well as reaction to other stress factors that may be unique to the environment before being recommended for cultivation. In the study reported herein, five (5) recently developed MSV resistant OPVs were evaluated along with an earlier version 
(DMR-LSR-Y) and one hybrid (Oba Super 2) as checks for two years at Ilorin, a typical southern guinea savanna ecology of Nigeria. The objective was to determine their yield and agronomic potentials with the view to recommending suitable varieties either for direct cultivation in this ecology or as replacement to the existing variety

\section{MATERIALS AND METHODS}

The field trials were conducted at the University of Ilorin Teaching and Research (T\&R) farm (Lat. 8 $29^{\prime} \mathrm{N} \& 8^{\circ} 30^{\prime} \mathrm{N}$; Long. $4^{\circ}$ $\left.30^{\prime} \mathrm{E} \& 4^{\circ} 32^{\prime} \mathrm{E}\right)$ during the late growing seasons of 2001 and 2002 respectively. Plantings were carried out during the month of July which is the common planting period for late maize in this ecology. The soil has been characterized as an alfisol and rainfall distribution is bimodal with peaks at May/June and September respectively. The experiment was set up each year as a randomized complete block design (RCBD) with four replications. The plot size consisted of four rows, $5 \mathrm{~m}$ long with inter and intra row spacing of $0.75 \mathrm{~m} \mathrm{x}$ $0.5 \mathrm{~m}$. The characteristics of the genetic materials are presented in Table 1. Three seeds were planted/hill but later thinned to two/hill to give a plant population of approximately 53,333 plans/ha. Crop management practices included weed control with pre-emergence application of herbicide (Attrazine of $80 \%$ wettable powder). The herbicide was applied at the rate of $100 \mathrm{ml}$ to 20 liters of water and was supplemented each year by one hoe weeding. Fertilizer application was carried out as splitdosage at the rate of $80 \mathrm{kgN} / \mathrm{ha}, 60 \mathrm{~K}_{2} \mathrm{O} / \mathrm{ha}$ and $60 \mathrm{P}_{2} \mathrm{O}_{5}$ at three weeks after planting (3WAP) and at anthesis (7WAP), using compound fertilizer (NPK 20:10:10). Just before flowering, all plants from the two middle rows in a plot were counted and assessed for occurrence of foliar diseases (rust, blight, curvularia leaf spot and streak). Only plants with obvious infection signs covering more than $50 \%$ of the leaf surfaces were counted and expressed as a percentage of total stand count in a plot. Data were also collected from the two middle rows from each plot on days to mid-flowering (tasseling, anthesis and silking), plant and ear heights, ear aspect, ear number (ENO) and grain yield. Anthesis-silkinginterval (ASI) was estimated as the interval in days between mid-anthesis and silking. Grain yield was first obtained as kilogram/plot before being converted into tons/ha after adjusting to $12 \%$ moisture content. At harvest, plants from the two middle rows were also rated on a scale of 1 (Excellent) to 5 (Very poor) for husk cover, plant and ear aspects and lodging characteristics (stalk \& root). The experiment was repeated in the 2002 late cropping season and the same data as for 2001 were also collected. Data collected were subjected to analyses of variance (ANOVA) first on individual year basis before a combined ANOVA over years. Due to very low incidence of both rust and streak in the two transformed using arcsine transformation (Snedecor and Cochran, 1967). However, since ANOVA did not detect any significant difference between transformed and untransformed values, untransformed values are hereby presented for the two characters. Pertinent means were thereafter separated by use of the least significant difference (LSD) according to Steel and Torrie (1980). years of evaluation, the two parameters were dropped from the analyses. Data on blight and curvularia leaf spot were first.

\section{RESULTS}

The two years differed significantly $(P=0.05)$ for days to anthesis and stalk lodging but neither for other agronomic parameters nor leaf disease incidence (Table 2). Rainfall amount and distribution during the growing periods of both years (Fig. 1) also showed that 2001 and 2002 rainfall was evenly distributed throughout the flowering/grain filling periods of September and October, 2002 while in 2001 , there was early on set of terminal drought.

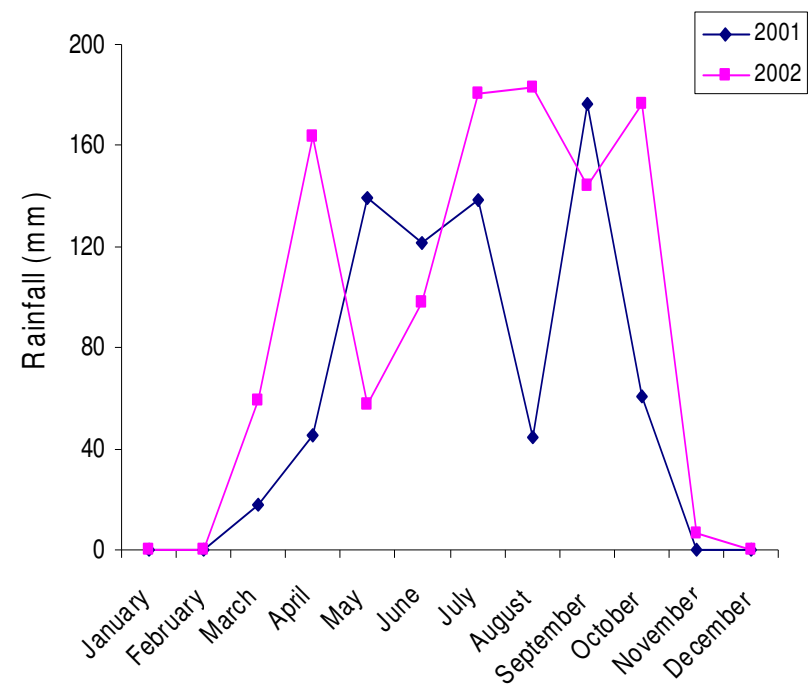

Figure 1. Rainfall distribution for llorin for 2001 and 2002 
Olaoye G.

The genotypes attained anthesis earlier in 2001 than in 2002 by two (2) days but with corresponding higher stalk and root lodging ratings. However, ASI and plant aspect remained relatively unaffected by differences in growing conditions between the two years. Although incidence of leaf diseases (Blight and Curvularia) were higher in 2002, differences between the two years were non significant for these parameters. Grain yield and related traits except ear placement and husk cover differed significantly (P 0.05 $\leq 0.01$ ) between the two years (Table 3). In consonance with higher ENO, grain yield was significantly higher in 2002 by $1.68 \mathrm{t}^{\mathrm{h}} \mathrm{ha}^{-1}$, compared to 2001, representing $30.2 \%$ yield increase. However, this increase was accompanied by higher grain moisture content and lower rating for ear aspect in the genotypes. Although ear placement was higher in 2002 cropping season, difference between years for this trait was not significant.

Differences among genotypes were significant for days to anthesis, lodging characteristics and disease incidence ratings but not for ASI and plant aspect (Table 2). The new generations of MSV resistant genotypes except Acr 91 Suwan-1-SR C1 attained

Table 1: Pedigree and grain characteristics of the Experimental Materials.

\begin{tabular}{lllll}
\hline S/N & Variety & Parent Population & Origin & Grain Type \\
\hline 1. & AK-9528-DMRSR & Pop 28 SR & IITA/CIMMYT & Flint/Dent \\
2. & IK.91 TZL Comp 3-Y C C & TZL Comp 3 & IITA & Flint/Dent \\
3. & Acr. 91 Suwan-1-Sr C & Suwan-1 & Thailand/IITA & Flint \\
4. & TZB-SR SGY & TZB-SR & Nigeria/IITA & Flint/Dent \\
5. & Ikenne 88 TZSR-Y-1 & TZSR-Y-1 & IITA & Flint/Dent \\
6. & Oba Super 2 & Hybrid Check & IITA/Pioneer & Flint \\
7. & DMR-LSR-Y & OPV Check & IITA & Flint/Dent \\
\hline
\end{tabular}

OPV; Open Pollinated variety.

Table 2: Effects of years on flowering traits, lodging characteristics and disease rating (\%) in seven MSV resistant genotypes (Ilorin, Nigeria).

\begin{tabular}{|c|c|c|c|c|c|c|c|}
\hline \multirow[b]{2}{*}{ Year } & \multicolumn{2}{|c|}{ Flowering characteristics } & \multirow[b]{2}{*}{ Plant aspect } & \multicolumn{2}{|c|}{ Lodging characteristics } & \multicolumn{2}{|c|}{ Leaf disease rating $(\%)$} \\
\hline & Days to Anthesis (no) & ASI (no) & & Stalk lodging & Root lodging & Blight & Curvularia leaf spot \\
\hline 2001 & 64 & 2.8 & 2.45 & 2.46 & 1.96 & 6.39 & 5.91 \\
\hline 2002 & 66 & 3.1 & 2.43 & 2.36 & 1.86 & 6.73 & 5.58 \\
\hline $\mathrm{LSD} \propto 0.05$ & 0.75 & Ns & Ns & 0.08 & Ns & ns & Ns \\
\hline
\end{tabular}

$*, * *$; significant at 0.05 and 0.01 levels of probability, respectively.

Table 3: Genotypic means for flowering traits, lodging characteristics and disease rating (\%) in seven MSV resistant genotypes (Ilorin, Nigeria).

\begin{tabular}{|c|c|c|c|c|c|c|c|}
\hline & \multicolumn{3}{|c|}{ Flowering characteristics } & \multicolumn{2}{|c|}{ Lodging characteristics } & \multicolumn{2}{|c|}{ Leaf disease rating $(\%)$} \\
\hline Genotype & Days to Anthesis & ASI & Plant aspect & Stalk lodging & Root lodging & Blight & Curvularia leaf spot \\
\hline AK-9528-DMRSR & 66 & 2.3 & 2.38 & 2.36 & 1.50 & 7.07 & 6.49 \\
\hline IK.91 TZL Comp 3-Y C1 & 65 & 2.6 & 2.38 & 2.13 & 2.00 & 6.44 & 4.55 \\
\hline Acr. 91 Suwan-1-Sr C1 & 64 & 3.0 & 2.63 & 2.00 & 2.25 & 7.14 & 5.24 \\
\hline TZB-SR SGY & 66 & 2.9 & 2.38 & 2.50 & 1.75 & 5.85 & 5.14 \\
\hline Ikenne 88 TZSR-Y-1 & 65 & 3.0 & 2.50 & 2.75 & 1.75 & 5.07 & 5.36 \\
\hline Oba Super $2+$ & 64 & 3.5 & 2.25 & 2.38 & 1.88 & 5.64 & 5.44 \\
\hline DMR-LSR-Y++ & 64 & 3.1 & 2.63 & 2.75 & 2.38 & 8.70 & 8.01 \\
\hline $\mathrm{LSD} \propto 0.05$ & 1.70 & ns & Ns & 0.57 & 0.53 & 1.58 & 1.35 \\
\hline \multicolumn{8}{|l|}{ F-test } \\
\hline Year (Y) & $60.07 *$ & 0.88 & 3.45 & $10.45^{*}$ & 50.16 & 4.57 & 2.16 \\
\hline Genotype (G) & $4.61 *$ & 1.24 & 4.46 & $8.46^{*}$ & $7.91 *$ & $227.83 * *$ & $5.19 * *$ \\
\hline$Y \times G$ & 3.41 & 1.08 & 2.43 & 4.89 & 2.79 & 137.66 & 1.08 \\
\hline$\% \mathrm{CV}$ & 1.91 & 1.13 & 14.65 & 10.56 & 12.56 & 18.05 & 17.45 \\
\hline
\end{tabular}

$*, * * ;$ significant at 0.05 and 0.01 levels of probability respectively.

,+++ ; Hybrid and Open pollinated variety (OPV) checks respectively. 
Evaluation for Maize Streak Virus Resistant Varieties

Table 4: Effects of years on grain yield and related traits in seven MSV resistant genotypes (Ilorin, Nigeria).

\begin{tabular}{llllllll}
\hline Year & $\begin{array}{l}\text { Grain yield } \\
(\mathrm{t} / \mathrm{ha})\end{array}$ & Ear number & $\begin{array}{l}\text { Ear } \\
(\mathrm{cm})\end{array}$ & height & Husk cover & Ear aspect & $\begin{array}{l}\text { Harvest moisture } \\
(\%)\end{array}$ \\
\hline 2001 & 3.89 & 33 & 63.4 & 2.25 & 2.46 & 11.15 \\
2002 & 5.57 & 36 & 66.1 & 2.11 & 3.39 & 14.21 \\
LSD $\alpha 0.05$ & 0.38 & 1.09 & Ns & Ns & 0.14 & 0.34 \\
\hline
\end{tabular}

*, **; significant at 0.05 and 0.01 levels of probability respectively.

Table 5: Genotypic means for grain yield and related traits in seven MSV resistant genotypes (Ilorin, Nigeria).

\begin{tabular}{|c|c|c|c|c|c|c|c|c|c|}
\hline & $\begin{array}{l}\text { Grain } \\
\text { yield } \\
\left(\mathrm{t} / \mathrm{ha}^{-1}\right)\end{array}$ & $\begin{array}{l}\text { Ear } \\
\text { number }\end{array}$ & Ear height $(\mathrm{cm})$ & $\begin{array}{l}\text { Husk } \\
\text { cover }\end{array}$ & Ear aspect & $\begin{array}{l}\text { Harvest } \\
\text { moist } \\
\text { ure }(\%)\end{array}$ & $\begin{array}{l}\text { Ranking } \\
\text { based } \\
\text { on grain } \\
\text { yield }\end{array}$ & \multicolumn{2}{|c|}{$\begin{array}{l}\% \text { yield advantage } \\
\text { or loss over } \\
\text { best check }\end{array}$} \\
\hline Genotypes & & & & & & & & Hybrid & OPV \\
\hline AK-9528-DMRSR & 4.59 & 33 & 62.3 & 2.38 & 3.00 & 12.50 & $6^{\text {th }}$ & -12.90 & 28.94 \\
\hline IK.91 TZL Comp 3-Y C1 & 4.61 & 36 & 69.6 & 2.38 & 3.00 & 12.83 & $5^{\text {th }}$ & -12.52 & 29.49 \\
\hline Acr. 91 Suwan-1-Sr C1 & 5.25 & 36 & 61.1 & 2.25 & 3.00 & 12.54 & $2^{\text {nd }}$ & -0.38 & 47.47 \\
\hline TZB-SR SGY & 4.63 & 37 & 59.3 & 1.88 & 3.00 & 12.80 & $4^{\text {th }}$ & -12.14 & 30.06 \\
\hline Ikenne 88 TZSR-Y-1 & 4.91 & 34 & 66.9 & 1.63 & 3.00 & 12.85 & $3^{\text {rd }}$ & -6.83 & 37.92 \\
\hline Oba Super 2+ & 5.27 & 33 & 66.5 & 2.75 & 2.5 & 12.25 & $1^{\text {st }}$ & & \\
\hline DMR-LSR-Y++ & 3.56 & 31 & 67.7 & 2.00 & 3.00 & 13.01 & $7^{\text {th }}$ & & \\
\hline Genotype Mean & 4.73 & 34.32 & 64.8 & 2.18 & 2.93 & 12.68 & & & \\
\hline $\mathrm{LSD} \propto 0.05$ & 0.83 & 3.56 & Ns & 0.53 & Ns & Ns & & & \\
\hline F-test & & & & & & & & & \\
\hline Year (Y) & $91.55 * *$ & $138.24^{*}$ & 105.88 & 2.16 & $12.07 * *$ & $25.25 * *$ & & & \\
\hline Genotype (G) & $2.26^{*}$ & $43.87 * *$ & 119.98 & $4.58 * *$ & 0.29 & 0.39 & & & \\
\hline$Y \times G$ & 1.34 & $35.20 *$ & 116.58 & 1.45 & 0.41 & 0.80 & & & \\
\hline$\% \mathrm{CV}$ & 17.56 & 7.23 & 11.79 & 18.56 & 15.63 & 7.22 & & & \\
\hline
\end{tabular}

*, **; significant at 0.05 and 0.01 levels of probability respectively.

,+++ ; Hybrid and Open pollinated variety (OPV) checks respectively.

Table 6: Interactive effects of genotype $x$ year for number of ears per plot and grain yield in seven MSV resistant varieties (Ilorin, Nigeria).

\begin{tabular}{|c|c|c|c|c|}
\hline \multirow[b]{3}{*}{ Genotype } & \multicolumn{2}{|c|}{ Ear number } & \multicolumn{2}{|c|}{ Grain Yield $\left(\mathrm{t} / \mathrm{ha}^{-1}\right)$} \\
\hline & \multicolumn{2}{|c|}{ Year } & \multicolumn{2}{|c|}{ Year } \\
\hline & 2001 & 2002 & 2001 & 2002 \\
\hline AK-9528-DMRSR & 29 & 36 & 3.49 & 5.70 \\
\hline IK.91 TZL Comp 3-Y C1 & 36 & 37 & 3.80 & 5.42 \\
\hline Acr. 91 Suwan-1-Sr C1 & 35 & 38 & 4.41 & 6.10 \\
\hline TZB-SR SGY & 39 & 35 & 4.06 & 5.20 \\
\hline Ikenne 88 TZSR-Y-1 & 33 & 35 & 4.56 & 5.26 \\
\hline Oba Super 2+ & 31 & 36 & 4.25 & 6.29 \\
\hline DMR-LSR-Y++ & 26 & 35 & 2.87 & 5.06 \\
\hline $\mathrm{LSD} \propto 0.05$ & & & & \\
\hline
\end{tabular}

,+++ ; Hybrid and Open pollinated variety (OPV) checks respectively. 
anthesis later than the two check varieties (Oba Super 2 and DMR-LSR-Y). However, ASI was shorter by 1-2 days for all genotypes compared to hybrid check. Acr 91 Suwan-1SR $\mathrm{C}_{1}$ and $\mathrm{AK}$ 9528-DMRSR rated better for stalk and root lodging while the OPV check was the worst for the two characters. The genotypes showed slight susceptibility to both blight and curvularial leaf diseases, ranging from $5.1 \%$ in Ikenne 88 TZSR-Y-1 to $8.1 \%$ in the OPV check for leaf blight and from $4.6 \%$ in IK 91 TZL Comp 3-Y C $\mathrm{C}_{1}$ to $8.4 \%$ also in the OPV check for curvularia leaf spot. However, the lowest incidence of leaf diseases recorded for Ikenne 88 TZSR-Y-1 and TZB-SR-SGY differed significantly only from that of the OPV variety.

Genotypic differences were significant only for grain yield, ENO and husk cover (Table 3). Oba super 2 ranked best for grain yield but did not differ in yield potential from any of the new generations of MSV resistant varieties. However, along with Acr. 91 Suwan-1-Sr C1 which ranked second for grain yield, this variety yielded higher than the OPV check by more than $32 \%$. The OPV check was also the latest to attain maturity as indicated by the highest grain moisture at harvest. Two of the new generations of MSV resistant varieties (TZB-SR-SGY and Ikenne 88 TZSR-Y-1) were superior for husk cover while the hybrid check had the worst rating for this character. The genotypes did not differ significantly for ear aspect, a subjective rating which includes factors such as yield, appearance of the grain and ear rot.

Means for the interactive effects of genotype by year ( $\mathrm{G} \times \mathrm{Y}$ ) was significant for ENO but not for grain yield (Table 4). Two genotypes (AK 9528-DMRSR and the OPV check (DMR-LSR-Y)) showed high disparity in ENO between the two years with differences of 7 and 9 ears/plot respectively. IK 91 TZL Comp 3-Y $\mathrm{C}_{1}$ was the most stable of all the entries for ENO, with a difference of one (1) ear between the two years. Genotypic differences for grain yield between the two years (although nonsignficant) were also high and it ranged from $13.3 \%$ in Ikenne 88 TZSR$\mathrm{Y}-1$ to $38.8 \%$ in AK-9528-DMRSR. Hybrid check also demonstrated instability of performance for grain yield with a difference of $37.4 \%$ yield loss in 2001 compared to 2002 .

\section{DISCUSSION}

Days to anthesis often reveal differences in maturity among genotypes but may also be a reflection of weather pattern (temperature, available soil moisture, etc.) during crop's reproductive phase, which may stimulate plants to speed up the process of maturation. The genotypes attained anthesis earlier by two (2) days in 2001 when rainfall dropped sharply compared to 2002 with even distribution during the latter part of the growing period. However, rating for ear aspect in the genotypes was better in 2001 when the volume of rainfall was low in October and November that year which also coincided with period of crop maturity compared to similar period in 2002.

Rainfall amount and distribution during the growing periods in the two years, played significant role in the expression of genotypes' potential in this study. For example, rainfall was evenly distributed throughout the flowering/grain filling period of September and October, 2002. This condition favoured accumulation, and translocation of photo-assimilates in the genotypes with corresponding bigger ear size in 2002, subsequently higher grain yield in all the genotypes. High soil moisture at maturity period also reduced termite infestation, consequently, lower stalk and root lodging. However, incidence of leaf blight was also higher in 2002, a condition that is often encouraged by high moisture during the growing period (Ekpo and Esuruoso, 1977; Agrios, 1988; Amadi, 1998). The desire of maize breeders is that increased grain yield would be associated with the streak resistant gene block accompanied by negligible changes, if any, in other traits (Fakorede et al., 2001). In this study, new generations of MSV varieties were superior to OPV check both for grain yield and incidence of leaf diseases, indicating that despite the yield improvement, the genes for resistance to the causal organisms have not been eroded. Nonsignificance $\mathrm{G} \times \mathrm{Y}$ interaction effect for grain yield could be attributed to instability in performance of AK 9528-DMRSR and OPV check (DMR-LSR-Y) which had poor yield in 2001 cropping season and which was also reflected in wide disparity in grain yields obtained from both genotypes in the two years.

\section{CONCLUSION}

The major focus in varietal evaluation is to identify superior genotypes that could replace existing cultivars and/or as sources of genes for the extraction of inbred lines aimed at development of productive varieties. Acr 91 Suwan-1-SR $\mathrm{C}_{1}$ was the most productive of the new generations of MSV resistant varieties with the highest yield advantage of 32 percent (\%) over the OPV check. It also compared favourably with the hybrid check for grain 
yield. The variety can therefore serve as useful replacement to DMRLSR-Y and also as source of genes for future maize breeding activities in the development of superior maize varieties for the southern guinea savanna ecology

\section{REFERENCES}

Agrios, N.G. 1988. Plant Pathology. Acad. Press, London. 803pp Amadi, J.E. 1998. The effects of growing season on Cercospora leaf spot diseaseseverity and grain yield. Centrepoint Science Edition 8 (1V): 47-55.

Ekpo, E.J. and O.F. Esuruoso. 1977. Factors affecting spore germination in cowpea isolate of Cercospora cruenta Sacc. Phytopathol 89:249-255.

Fajemisin, J.M. 1984. Basic constraints to maize productivity in tropical Africa. Paper presented at the U.S. Universities/CIMMYT maize conference. CIMMYT. Mexico. August 8-15, 1984.

Fajemisin, J.M. 1985. Maize diseases in Africa and their role in varietal improvement process. Paper presented at the Maize Regional Workshop for Eastern ands Southern Africa held at Lusaka, Zambia. March 10-17, 1985.

Fajemisin, J.M., M. Bjarnasan, S.K. Kim, Y. Efron and Z.T. Dabrowski 1984. Effect of maize streak virus on maize productivity. Paper presented at the $14^{\text {th }}$ conference of Nigeria Society for Plant Protection. University of Ibadan, Nigeria March 12-15, 1984.

Fajemisin, J. E.; Efron Y; Kim. S.K.; Khadr E.H; Dabroski Z. T. Mareck J.H. Bajarson M; Parkinson V; Everet, L. A and Daillo A., 1985. Population and varietal development in maize for tropical Africa through resistance breeding approach. In: Brandolini, A. and Salami, F. (eds). The strategies for maize production and Improvement in the tropics. FAO, Italy. pp. 285-408.
Fakorede, M.A.B., J.M. Fajemisin, J.L. Ladipo, S.O. Ajala and S.K. Kim. 2001. Development and regional deployment of streak virus maize germplasm: an overview. 503-516 in Jacqueline d'A Hughes and Babajide O Odu (eds). Plant Virology in SubSaharan Africa. Proc. of a conference organized by the International Institute of Tropical Agriculture, Ibadan $4^{\text {th }}-8^{\text {th }}$ June, 2001.

Mihm, J.A. 1994. Maize pest managementmultiple insect and disease resistant varieties are the key to success. 176181. in David C. Jewell, Stephen R. Waddington, Joel K. Ransom and Kevin V. Pixley (eds.) Maize research for stress environments. Proceedings of the Fourth Eastern and Southern Africa Regional Maize Conference Harare Zimbabwe. 28 $8^{\text {th }}$ March $-1^{\text {st }}$ April, 1994.

laokojo, S.A. and J.E. Iken. 1999. Productivity of maize genotypes in downy mildew endemic zone of south western Nigeria. Nigerian J. Genetics 14:6468

Olaokojo, S.A. and J.E. Iken. 2001. Yield performance and stability of some improved maize (Zea mays L.) varieties. Moor Journal of Agricultural Research 2:21-24.

Snedecor, G.W. and W.G. Cochran, 1967. Statistical Methods. Iowa States University Press, Ames Iowa, USA. 593pp.

Steel, R.G.D. and J.H. Torrie 1980. Principles and Procedures of Statistics. A Biometrical Approach. $2^{\text {nd }}$ Edition. McGraw Hill Book Inc. New York. 580pp. 